\title{
Coordination compounds from 1,3,5-triazine-derived multi- directional ligands: application in oxidation catalysis
}

\author{
Patrick Gamez ${ }^{\mathrm{a}, *, 1}$, Paul de Hoog ${ }^{\mathrm{a}}$, Martin Lutz ${ }^{\mathrm{b}}$, Anthony L. Spek ${ }^{\mathrm{b}}$, Jan Reedijk ${ }^{\mathrm{a}, *}$ \\ ${ }^{a}$ Leiden Institute of Chemistry, Gorlaeus Laboratories, Leiden University, P.O. Box 9502, 2300 RA Leiden, The Netherlands \\ ${ }^{\mathrm{b}}$ Bijvoet Center for Biomolecular Research, Crystal and Structural Chemistry, Utrecht University, Padualaan 8, 3584 CH Utrecht, The Netherlands
}

Received 26 February 2003; received in revised form 19 March 2003; accepted 22 March 2003

\begin{abstract}
A series of 1,3,5-triazine- and 2,2'-dipyridylamine-based ligands have been prepared and the crystal structure from one of them was solved. The coordination of these dendritic multi-directional ligands with various metal salts led to attractive supramolecular architectures. In particular, an unprecedented 1D ladder coordination polymer resulted from the reaction of copper(II) nitrate and $\mathbf{2 b}$. Reaction of nickel(II) perchlorate with $\mathbf{2 b}$ led to the formation of a new dinuclear nickel complex for which the crystal structure is discussed. Finally, the polynucleating ligands $\mathbf{2 b}-\mathbf{2} \mathbf{e}$ were used with copper(II) nitrate to catalyze the oxidation of 3,5-di-tertbutylcatechol. The best catalytic system was obtained when the first-generation dendrimer $2 \mathrm{e}$ was employed as a ligand for $\mathrm{Cu}(\mathrm{II})$, showing that the stability of the catalyst could be improved by incorporating $2,2^{\prime}$-dipyridylamine into a dendritic material.
\end{abstract}

(C) 2003 Elsevier B.V. All rights reserved.

Keywords: Copper complexes; Polydentate ligand; 1,3,5-Triazine; Pyridine; Catalysis

\section{Introduction}

The design and synthesis of supramolecular polynuclear metal complexes has been an area of rapid growth since the past 20 years [1-4]. During the last decade, a remarkable development in the preparation of self-assembled architecture through metal ion coordination has been observed [5]. The motivation behind much of this research work has been provided by the prospect of producing a wide range of purpose-built materials with predetermined structures and potential applications in separation, gas storage, molecular recognition and catalysis [6,7]. Many examples of such self-assembled architectures with complex and wonderfully efficient functions can be found in biological systems.

* Corresponding authors. Tel: + 31-71-527 4450; fax: +31-71-527 4671.

E-mail addresses: p.gamez@chem.leidenuniv.nl (P. Gamez), reedijk@chem.leidenuniv.nl (J. Reedijk).

1 Tel.: +31-71-527 4345; fax: +31-71-527 4451 .
Copper enzymes are part of these intricate and beautiful molecules which inspire many chemists who try to model their polymetallic active sites (catechol oxidase, quercetinase, laccase and so on) [8].

1,3,5-Triazine derivatives are widely used as herbicides [9], drugs [10] or polymers [11] like melamineformaldehyde that has excellent thermal and electrical properties. Furthermore, a very large number of supramolecular noncovalently bond assemblies between melamine and barbituric or cyanuric acid derivatives have been reported $[12,13]$, but only a few examples of $1,3,5$ triazine-containing ligands have been published so far $[14,15]$.

This paper describes the preparation of new rationally designed multidentate ligands and discusses their supramolecular coordination chemistry. The relatively simple synthetic pathway to these multi-directional $2,2^{\prime}$-dipyridylamino-derived ligands is based on the nucleophilic addition of primary and secondary amines to 2,4,6trichloro-1,3,5-triazine. A novel dendritic ligand is presented, as well as a new nickel complex. Finally, the polynucleating ligands are tested in the copper- 
catalyzed oxidation of 3,5-di-tert-butylcatechol (DTBC) to 3,5-di-tert-butylquinone (DTBQ).

\section{Experimental}

\subsection{Materials and methods}

All starting materials were commercially available and used as received. Infrared spectra were recorded on a Perkin-Elmer Paragon 1000 spectrophotometer equipped with a Golden Gate Diamond and peaks are reported in $\mathrm{cm}^{-1}$. ${ }^{1} \mathrm{H}$ NMR spectra were recorded on a JEOL JNM FX-200 (200 MHz) instrument. Chemical shifts are reported in $\delta$ (parts per million) relative to an internal standard of tetramethylsilane. $\mathrm{C}, \mathrm{H}$, and $\mathrm{N}$ analyses were performed on a Perkin-Elmer 2400 series. Dioxygen-uptake experiments (vide infra) were performed using an inhouse designed apparatus, which has been described in detail in our earlier publications $[16,17]$. The preparation of ligands $\mathbf{2 b}-\mathbf{2 d}$ was previously described [18].

\subsection{Synthesis of $N, N^{\prime}, N^{\prime \prime}, N^{\prime \prime \prime}-\{2,4-$ di $[$ (di-pyridin-2- \\ yl) amine $7-1,3,5$-triazine $\}-1,4,8,11$ - \\ tetraazacyclotetradecane (azadendtriz)}

$0.11 \mathrm{~g}(0.55 \mathrm{mmol})$ of 1,4,8,11-tetraazacyclotetradecane was introduced in double-necked $50 \mathrm{ml}$ roundbottom flask under argon. $5 \mathrm{ml}$ of THF and $3 \mathrm{ml}$ of $\mathrm{CH}_{3} \mathrm{CN}$ were added. $0.28 \mathrm{~g}(0.4 \mathrm{ml}, 2.20 \mathrm{mmol})$ of $N$ ethyldiisopropylamine (DIPEA) was added to the solution. Finally, $1 \mathrm{~g}(2.20 \mathrm{mmol})$ of 6-chloro- $N, N, N^{\prime}, N^{\prime}$ tetrapyridin-2-yl-1,3,5-triazine-2,4-diamine (cdpyatriz). The reaction mixture was refluxed for $48 \mathrm{~h}$. The white precipitate is filtered and washed with $5 \mathrm{ml} \mathrm{EtOH}$. After drying at $100{ }^{\circ} \mathrm{C}$ overnight, $0.74 \mathrm{~g}(0.396 \mathrm{mmol}, 72 \%$ yield) of azadendtriz (2e) was obtained as a white powder.

$\mathrm{C}_{102} \mathrm{H}_{84} \mathrm{~N}_{40}$ : molecular weight: $1870.03 \mathrm{~g} \mathrm{~mol}^{-1} .{ }^{1} \mathrm{H}$ NMR $\left(\mathrm{CDCl}_{3}, 200 \mathrm{MHz}\right) \delta 1.35\left(\mathrm{~m}, 4 \mathrm{H}, \mathrm{CH}_{2}\right), 2.93(\mathrm{~m}$, $\left.8 \mathrm{H}, \mathrm{CH}_{2}\right), 3.07\left(\mathrm{~m}, 8 \mathrm{H}, \mathrm{CH}_{2}\right), 7.04(\mathrm{~d}, 16 \mathrm{H}, 3-\mathrm{py}-\mathrm{H})$, 7.39 (dd, 16H, 5-py-H), 7.52 (dd, 16H, 4-py-H), 8.32 (d, $16 \mathrm{H}, 6-\mathrm{py}-\mathrm{H}) \mathrm{ppm} ;{ }^{13} \mathrm{C} \mathrm{NMR}\left(\mathrm{CDCl}_{3}, 50 \mathrm{MHz}\right) \delta 28.1$, 48.1, 49.8, 120.5, 122.7, 137.0, 148.2, 155.3, $165.2 \mathrm{ppm;}$ IR (neat) 3054, 2931, 1526, 1462, 1366, 1254, 996, 807, $775,744,668,408 \mathrm{~cm}^{-1}$; MS (MALDI-TOF): $\mathrm{m} / z 1870$ $\left[\mathrm{M}^{+}\right]$; Elemental analyses: Found (Calc.): C, 65.00 (65.51); H, 4.20 (4.53); N, 29.80 (29.96)\%.

\section{3. $\left[\mathrm{Ni}_{2}(\mathbf{2 b})_{2}\left(\mathrm{H}_{2} \mathrm{O}\right)_{2}(\mathrm{MeOH})_{2}\right]\left(\mathrm{ClO}_{4}\right)_{4}(\mathrm{MeOH})_{6}$} (3)

A solution of dpyatriz $(65 \mathrm{mg}, 0.11 \mathrm{mmol})$ in methanol $(15 \mathrm{ml})$ was added dropwise to a solution of $\mathrm{Ni}\left(\mathrm{ClO}_{4}\right)_{2} \cdot 6 \mathrm{H}_{2} \mathrm{O}(121 \mathrm{mg}, 0.33 \mathrm{mmol})$ and $1 \mathrm{ml}$ of trimethyl orthoformate (mof) in methanol (15 ml). 154 $\mathrm{mg}$ of an air-sensitive light-purple crystalline compound formed after a few hours which was isolated and dried (0.08 mmol, 70\%). IR (neat) 3386, 1605, 1546, 1469, 1373, 1055, 1003, 967, 769, $621 \mathrm{~cm}^{-1}$; Found: C, 44.45; $\mathrm{H}, 4.11 ; \mathrm{N}, 17.22$. Calc. for $\mathrm{C}_{74} \mathrm{H}_{84} \mathrm{Cl}_{4} \mathrm{~N}_{24} \mathrm{Ni}_{2} \mathrm{O}_{26}$ : C, 44.78; H, 4.27; N, 16.94\%.

\subsection{Dioxygen-uptake measurements}

In a typical quantitative, time-resolved dioxygenuptake experiment, one compartment of a special twocompartment reaction vessel was filled with $5 \mathrm{ml}$ of the $0.01 \mathrm{M}$ copper(II)/ligand $\mathbf{2 a}-\mathbf{2 e}$ aqueous solution and the other with $10 \mathrm{ml}$ of the catechol toluene solution. Intense shaking in a dioxygen atmosphere combined these solutions and started the reaction. The resulting reaction emulsion was $3.33 \mathrm{mM}$ in copper and $0.2 \mathrm{M}$ in DTBC. All oxidation reactions were performed at $25^{\circ} \mathrm{C}$ under pure dioxygen at atmospheric pressure. These are the conditions referred to as standard conditions. In this particular case, a 2,2'-dipyridylamine unit/Cu ratio of 1 and a $\mathrm{NaOMe} / \mathrm{Cu}$ ratio of 2 were used. The conversion was determined both from the amount of dioxygen consumed and by gas chromatography (GC) analysis of the reaction mixture. The reaction selectivity was determined by GC.

\section{5. $X$-ray structure determinations}

Data collection and cell refinement were carried out on a Nonius KappaCCD diffractometer, using graphitemonochromated Mo K $\alpha$ radiation $(\lambda=0.71073 \AA)$. The structures were solved by direct methods (SHELXS-97) [19] and refined with SHELXL-97 [20] against $F^{2}$ of all reflections. Non-hydrogen atoms were refined with anisotropic displacement parameters, hydrogen atoms were refined as rigid groups. Structure 2e contains large voids with volumes of $97.7 \AA^{3}$ per unit cell. These voids are filled with disordered solvent molecules. Their contribution to the structure factors was secured by back-Fourier transformation using the SQUEEZE routine of the program PLATON [21], amounting to 20 electrons per unit cell. Details of the structure determinations are given in Table 1.

\section{Results and discussion}

\subsection{Ligand synthesis and X-ray structure}

The present 1,3,5-triazine-containing compounds are synthesized from 2,4,6-trichloro-1,3,5-triazine (1) and a nucleophile. By controlling the temperature, 2,4,6-trisubstituted triazines can be prepared by sequential selective nucleophilic addition of amines (Fig. 1). The 
Table 1

Crystal data and details of data collection and structure refinement for 2e and $\mathbf{3}^{\mathrm{a}}$

\begin{tabular}{|c|c|c|}
\hline & Ligand $2 \mathrm{e}$ & Complex 3 \\
\hline Empirical formu- & $\mathrm{C}_{102} \mathrm{H}_{84} \mathrm{~N}_{40}+$ disor- & $\mathrm{C}_{68} \mathrm{H}_{60} \mathrm{~N}_{24} \mathrm{Ni}_{2} \mathrm{O}_{4}$ \\
\hline Formula weight & $1870.09^{\mathrm{b}}$ & 1984.87 \\
\hline Crystal system & triclinic & monoclinic \\
\hline Space group & $P \overline{1}$ (no. 2) & $P 2_{1} / c$ (no. 14 ) \\
\hline \multicolumn{3}{|l|}{$\begin{array}{l}\text { Unit cell dimen- } \\
\text { sions }\end{array}$} \\
\hline$a(\AA)$ & $12.2893(2)$ & $13.2869(2)$ \\
\hline$b(\AA ̊)$ & $12.3045(3)$ & $14.5121(2)$ \\
\hline$c(\AA)$ & $16.6352(4)$ & $22.6333(3)$ \\
\hline$\beta\left(^{\circ}\right)$ & $104.5689(9)$ & $91.9130(6)$ \\
\hline$V\left(\AA^{3}\right)$ & $2366.71(9)$ & $4361.74(11)$ \\
\hline$Z$ & 1 & 2 \\
\hline$D_{\text {calc }}\left(\mathrm{g} \mathrm{cm}^{-3}\right)$ & $1.312^{\mathrm{b}}$ & 1.511 \\
\hline$F\left(\begin{array}{lll}0 & 0 & 0\end{array}\right)$ & $976^{b}$ & 2056 \\
\hline$\mu\left(\mathrm{mm}^{-1}\right)$ & $0.085^{\mathrm{b}}$ & 0.645 \\
\hline $\begin{array}{l}\text { Crystal dimen- } \\
\text { sions }(\mathrm{mm})\end{array}$ & $0.18 \times 0.40 \times 0.48$ & $0.42 \times 0.21 \times 0.09$ \\
\hline Temperature (K) & 150 & 150 \\
\hline$\Theta_{\min , \max }\left({ }^{\circ}\right)$ & $1.3,24.6$ & $1.5,25.7$ \\
\hline $\begin{array}{l}\text { Reflections col- } \\
\text { lected }\end{array}$ & 30517 & 53442 \\
\hline $\begin{array}{l}\text { Independent re- } \\
\text { flections }\end{array}$ & 7951 & 8274 \\
\hline$R\left[F_{0}>4 \sigma\left(F_{0}\right)\right]$ & 0.0526 & 0.0353 \\
\hline$R$ (all data) & 0.0849 & 0.0502 \\
\hline$w R_{2}$ (all data) & 0.1478 & 0.1002 \\
\hline$\Delta \rho_{\min , \max }\left(\mathrm{e} \AA^{-3}\right)$ & $-0.34 / 0.63$ & $-0.49 / 0.60$ \\
\hline
\end{tabular}

a Details in common: Mo K $\alpha, \lambda=0.71073 \AA$.

b Derived values do not contain the contribution of the disordered solvent.

yield of each substitution often exceeds $95 \%$ and the trisubstituted derivatives can be obtained in a one-pot synthesis. The preparation of ligands $\mathbf{2} \mathbf{b}-\mathbf{2} \mathbf{d}$ has been previously published [18]. $N, N^{\prime}, N^{\prime \prime}, N^{\prime \prime \prime}-\{2,4-\mathrm{Di}[(\mathrm{di}-$ pyridin-2-yl)amine]-1,3,5-triazine $\}$-1,4,8,11-tetraazacy-

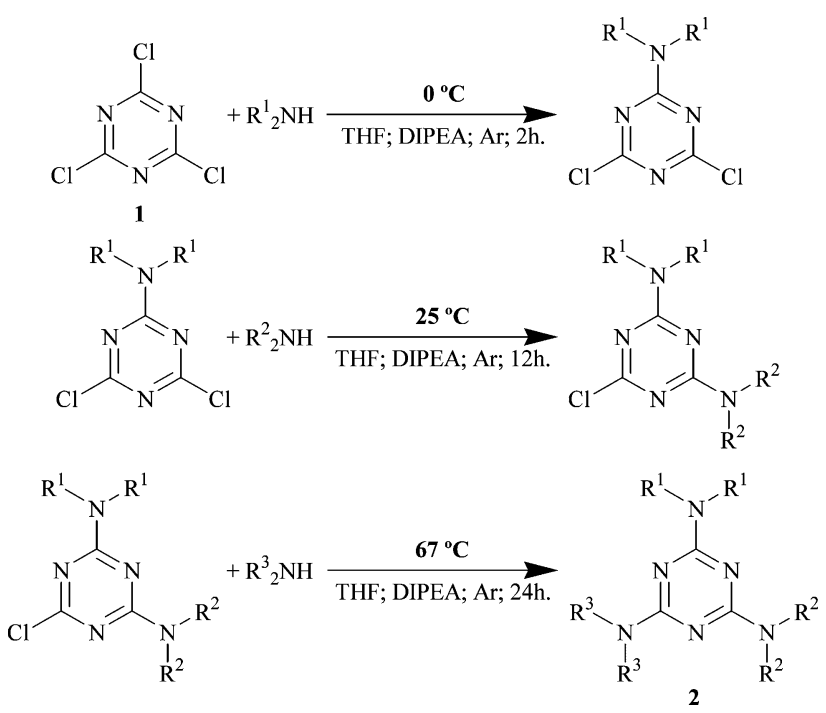

Fig. 1. Differential reactivity of 1,3,5-triazines. clotetradecane (2e, azadendtriz) is obtained in $72 \%$ yield from 2-chloro[4,6-(di-pyridin-2-yl-amino)]-\{1,3,5\}triazine [18] and the azacrown ether 1,4,8,11-tetraazacyclotetradecane (Fig. 2).

Single crystals of ligand $2 \mathrm{e}$ were obtained and analyzed by X-ray diffraction. Ligand $2 \mathrm{e}$ crystallizes in the triclinic space group $P \overline{1}$ (No. 2) and is located on an inversion center. A molecular plot of the crystal structure of ligand 2e is shown in Fig. 3. Azadendtriz presents eight binding sites. At this point, it should be realized that the nitrogen atoms of the triazine ring, as well as the conjugated nitrogen atoms at the 2,4,6positions are non-coordinating due to the delocalization of the electrons. Therefore, a metal ion cannot be accommodated in the macrocyclic site which has been intentionally used as building block for the preparation of the first-generation dendrimer 2e. Details of the structure determinations are given in Table 2.

\subsection{Coordination compounds obtained}

All these new ligands were imagined with the intention to coordinate several metal ions. Various coordination compounds were already prepared, especially from ligand 2b [22-24]. 2b can be regarded as a star-shaped ligand which is expected to bind three metal ions (Fig. 4). The arrangement of the resulting trinuclear units will then lead to the serendipitous [25] or the controlled [26] self-assembly of supramolecular architectures depending on the metal ion employed. Unexpected coordination networks are more likely awaited with metal centers like copper or zinc which can adopt different coordination geometries. A better control of the self-assembly process can be reached by combining judiciously shaped ligands with metal ions such as square-planar platinum or palladium coordinated where the number of kinetically inert and labile sites are limited.

Recently, an unpredicted but completely new coordination polymer showing a 1D ladder solid-state architecture was reported with $\mathbf{2 b}$ and copper(II) nitrate (Fig. 5) [23]. This particular self-assembly architectures have received little attention in comparison with 1D-rod, 2Dgrid or 3D-diamond infinite structures [4]. This is likely due to the difficulty to obtain a T-shaped geometry around the metal, which is required to obtain the ladder structure. In the present unprecedented example, the required $\mathrm{T}$-shape is brought by the ligand itself and not by the coordination mode of the metal ion (Fig. 5).

In this paper, a new complex resulting from the reaction of ligand $\mathbf{2 b}$ with nickel(II) perchlorate is reported. Single crystals suitable for X-ray diffraction were obtained and analyzed. Crystallographic data for complex $\mathbf{3}$ are collected in Table 2. 
<smiles>C/C=C\C(=C/C)N(C(/C=C\C)=C/c1ccccn1)c1nc(N(c2ccccn2)c2ccccn2)nc(N(c2ccccn2)c2ccccn2)n1</smiles><smiles>c1ccc(N(c2ccccn2)c2nc(NCCNc3nc(N(c4ccccn4)c4ccccn4)nc(N(c4ccccn4)c4ccccn4)n3)nc(N(c3ccccn3)c3ccccn3)n2)nc1</smiles>

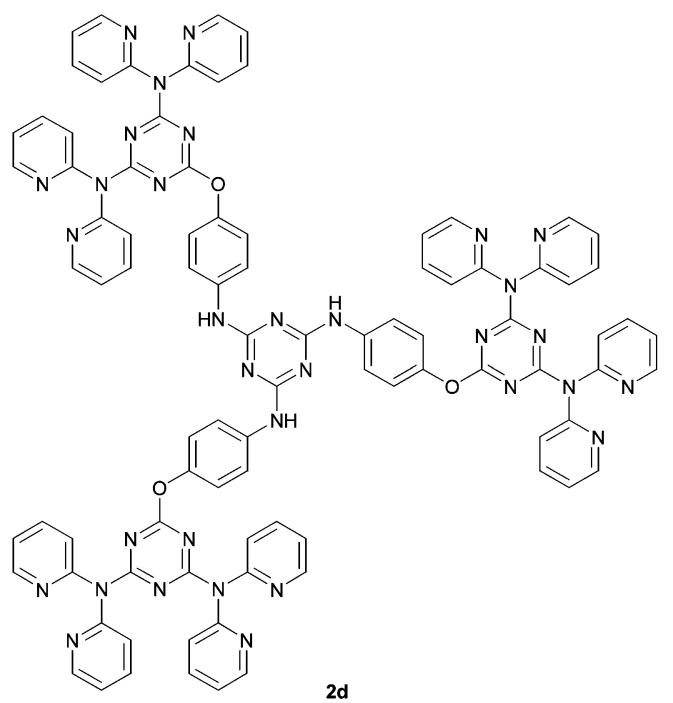

2d

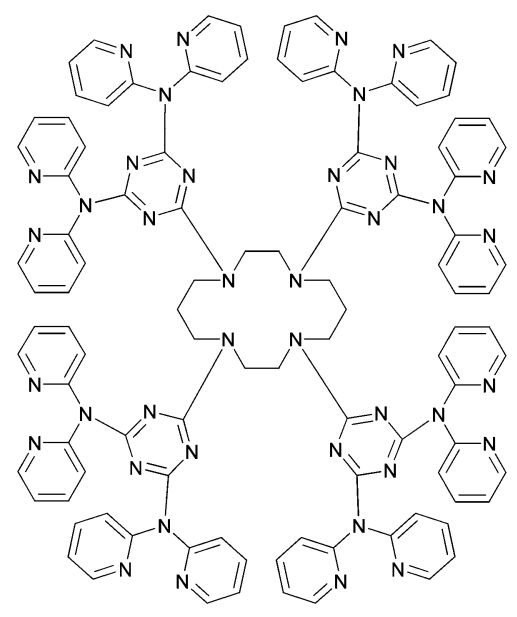

$2 e$

Fig. 2. Ligands prepared and tested in catechol oxidase activity.

\subsection{Description of the structure of}

$\left[\mathrm{Ni}_{2}(2 \mathrm{~b})_{2}\left(\mathrm{H}_{2} \mathrm{O}\right)_{2}(\mathrm{MeOH})_{2}\right]\left(\mathrm{ClO}_{4}\right)_{4}(\mathrm{MeOH})_{6}(\mathbf{3})$

Reaction of $\mathrm{Ni}\left(\mathrm{ClO}_{4}\right)_{2} \cdot 6 \mathrm{H}_{2} \mathrm{O}$ in methanol with $\mathbf{2 b}$ yields air-sensitive light-purple crystalline parallelepipeds of $\left[\mathrm{Ni}_{2}(\mathbf{2 b})_{2}\left(\mathrm{H}_{2} \mathrm{O}\right)_{2}(\mathrm{MeOH})_{2}\right]\left(\mathrm{ClO}_{4}\right)_{4}(\mathrm{MeOH})_{6}(\mathbf{3})$. A molecular plot of the crystal structure of $\mathbf{3}$ is shown in Fig. 6. Surprisingly, ligand $\mathbf{2 b}$ is not coordinated to three different nickel atoms, as aimed and successfully completed with copper (Fig. 5), but to only two of them. Consequently, complex 3 shows two free binding sites which may be used to coordinate other metal ions.

The nickel atom is located in a slightly distorted octahedral environment formed by two pairs of $\mathrm{N}$ coordinating 2-pyridyl groups belonging to two different ligands $\mathbf{2} \mathbf{b}$, one methanol molecule and one water

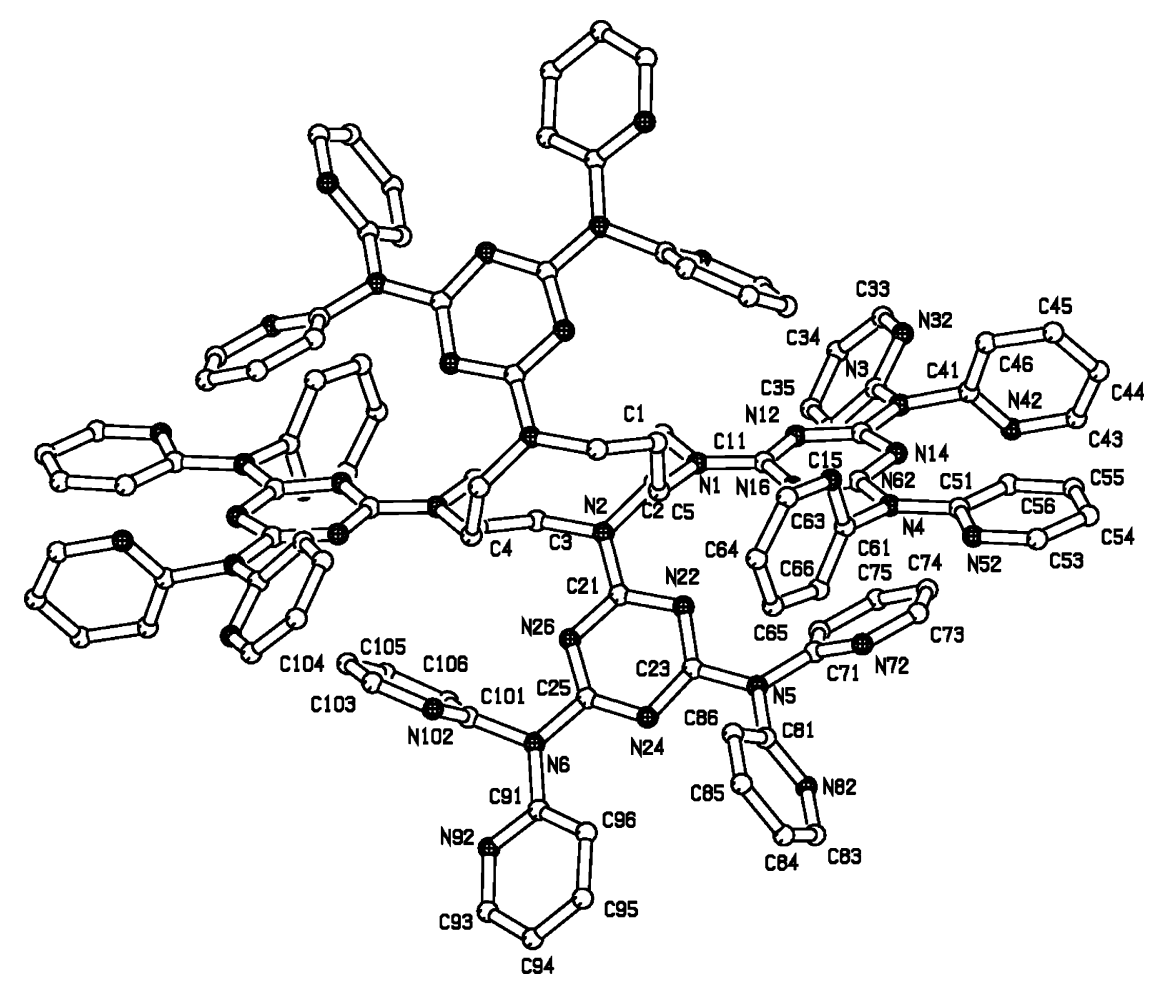

Fig. 3. Platon [21] projection for 2e. Hydrogen atoms are omitted for clarity. 
Table 2

Copper-catalyzed oxidation of DTBC ${ }^{\text {a }}$

\begin{tabular}{lllll}
\hline Ligand L & Cu/L ratio & \multicolumn{2}{c}{ Conversion\% } & Selectivity (\%) ${ }^{\mathrm{b}}$ \\
\cline { 3 - 4 } & & $1 \mathrm{~h}$ & $3 \mathrm{~h}$ \\
\hline $\mathbf{2 a}$ & 1 & $43^{\mathrm{c}}$ & $45^{\mathrm{d}}$ & 99 \\
$\mathbf{2 b}$ & 3 & 38 & $47^{\mathrm{d}}$ & 90 \\
$\mathbf{2 c}$ & 4 & 26 & $37^{\mathrm{d}}$ & 99 \\
$\mathbf{2 d}$ & 6 & 17 & $28^{\mathrm{d}}$ & 99 \\
$\mathbf{2 e}$ & 8 & 43 & $55^{\mathrm{e}}$ & 99 \\
\hline
\end{tabular}

${ }^{\text {a }}$ In all experiments a DTBC/Cu ratio of 60 was used (see Section 2).

b In DTBQ a minimal amount of a side product can be observed. It results from the partial oxidation of DTBC.

c $28 \%$ conversion after 5 min reaction time.

d A plateau was not reached at this point.

e $65 \%$ conversion after $6 \mathrm{~h}$ reaction time.

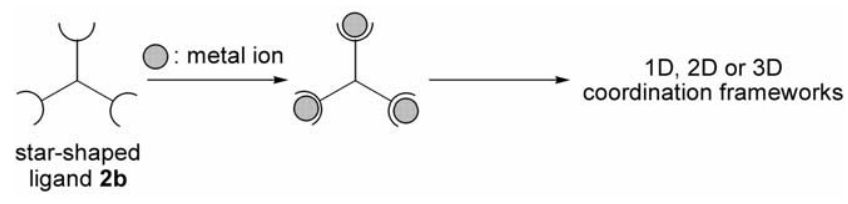

Fig. 4. Schematic representation of ligand $\mathbf{2 b}$ and its coordination compounds.

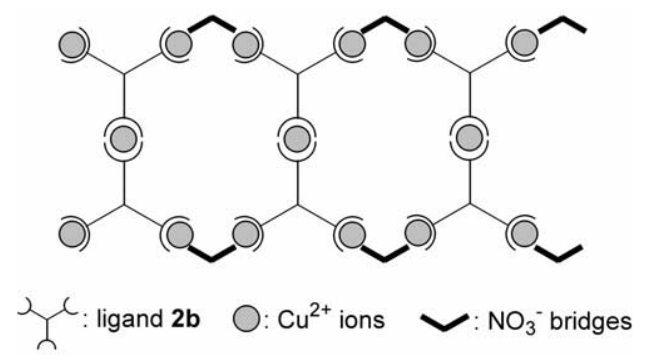

Fig. 5. 1D ladder coordination polymer.

molecule. The distortion is due to the twisted coordination of the rigid ligands $\mathbf{2} \mathbf{b}$. Thus, the axial angle $\mathrm{N}(31)_{\text {axial }}-\mathrm{Ni}(1)-\mathrm{O}(1)_{\text {axial }}$ is $175.31(7)^{\circ}$. The equatorial plane is formed by three nitrogen atoms from two different dpyatriz ligands and one oxygen atom of a water molecule. The $\mathrm{N}_{\text {equatorial }}-\mathrm{Ni}(1)-\mathrm{N}_{\text {equatorial }}$ and $\mathrm{O}_{\text {equatorial }}-\mathrm{Ni}(1)-\mathrm{N}_{\text {equatorial }}$ angles vary from $88.47(7)^{\circ}$ to $92.56(7)^{\circ}$. The in-plane $\mathrm{Cu}-\mathrm{N}$ distances of 2.0646(18) $\AA(\mathrm{Ni}(1)-\mathrm{N}(41)), 2.0817(19) \AA(\mathrm{Ni}(1)-\mathrm{N}(11))$ and $2.0986(18) \AA(\mathrm{Ni}(1)-\mathrm{N}(21))$ can be regarded as normal, as well as the $\mathrm{Ni}(1)-\mathrm{O}(2)$ distance of 2.0739(17) $\AA$. The axial positions are occupied by $\mathrm{N}(31)$ at a distance of 2.0824(18) $\AA$ and by the oxygen atom $\mathrm{O}(1)$ of a coordinated methanol molecule $(\mathrm{Ni}(1)-\mathrm{O}(1)=$ 2.1322(17) $\AA$ ). In addition, four non-coordinated perchlorate ions and six methanol molecules are located in the unit cell.

\subsection{Oxidation of DTBC}

Catechol oxidases are ubiquitous plant enzymes which catalyze the oxidation of ortho-diphenols to ortho-quinones in the presence of dioxygen [27,28]. These enzymes are characterized by a dinuclear copper active site [29].

The catecholase activity has been evaluated in a biphasic water/toluene solvent mixture at $25^{\circ} \mathrm{C}$ under a pure dioxygen atmosphere (Fig. 7). The reactions of the complexes, obtained in situ from $\mathbf{2 a}-\mathbf{2 e}$ and copper(II) nitrate in water, and DTBC in toluene were followed by measuring the dioxygen consumption using an inhouse designed apparatus [16]. The products of the oxidation were analyzed by GC by comparison with a commercially pure sample of DTBQ. The results are summarized in Table 2.

The use of 2,2'-dipyridylamine (2a) gave the best initial dioxygen-uptake with $28 \%$ conversion in $5 \mathrm{~min}$. But after $60 \mathrm{~min}$ the catalyst was found not active anymore and a plateau was reached, corresponding to the oxidation of $45 \%$ of the initial DTBC. The first dendritic ligand $\mathbf{2 b}$ led to the same conversion after a reaction time of $3 \mathrm{~h}$ but DTBQ was only obtained with a selectivity of $90 \%$ instead of $99 \%$. A side product corresponding to the oxidation of one phenolic group of DTBC was also detected. First-generation dendrimers $\mathbf{2 c}$ and $\mathbf{2 d}$ provided the less active catalytic systems, but unlike for $\mathbf{2 a}$, some activity was still present after $3 \mathrm{~h}$. The low reaction rates observed with these two triazine derivatives might be due to difficulties to produce dinuclear active species in the reaction mixture. This is not the case for $2 \mathrm{e}$ where the flexibility of the azacrown ether allows the dipyridyl units to be close enough in space to form dinuclear active copper entities (see crystal structure, Fig. 4). Thus, the catalyst obtained from copper(II) nitrate and 2e gave an activity comparable with the one with 2a. But in contrary with 2,2'dipyridylamine, the catalytic system is still working after $1 \mathrm{~h}$ reaction time and 55\% conversion was reached after $3 \mathrm{~h}$. The copper-2e complex was found to be the most active and stable catalyst tested and $65 \%$ of DTBC was oxidized in $6 \mathrm{~h}$ where no plateau was yet attained. Another possible explanation lies in the formation of the quinone itself. When the concentration of DTBQ reaches a level corresponding to the conversion of approximately half of the initial amount of substrate, the quinone starts to compete with 2,2'-dipyridyl units to complex the copper ions, leading to catalyst inactivation. This may explain the poor stability of the catalyst obtained with 2a where the complexation of the copper ions by two 2,2'-dipyridyl units, stabilizing the catalyst, can probably not occur while it is obviously possible with the dendritic ligands $[23,24]$. 


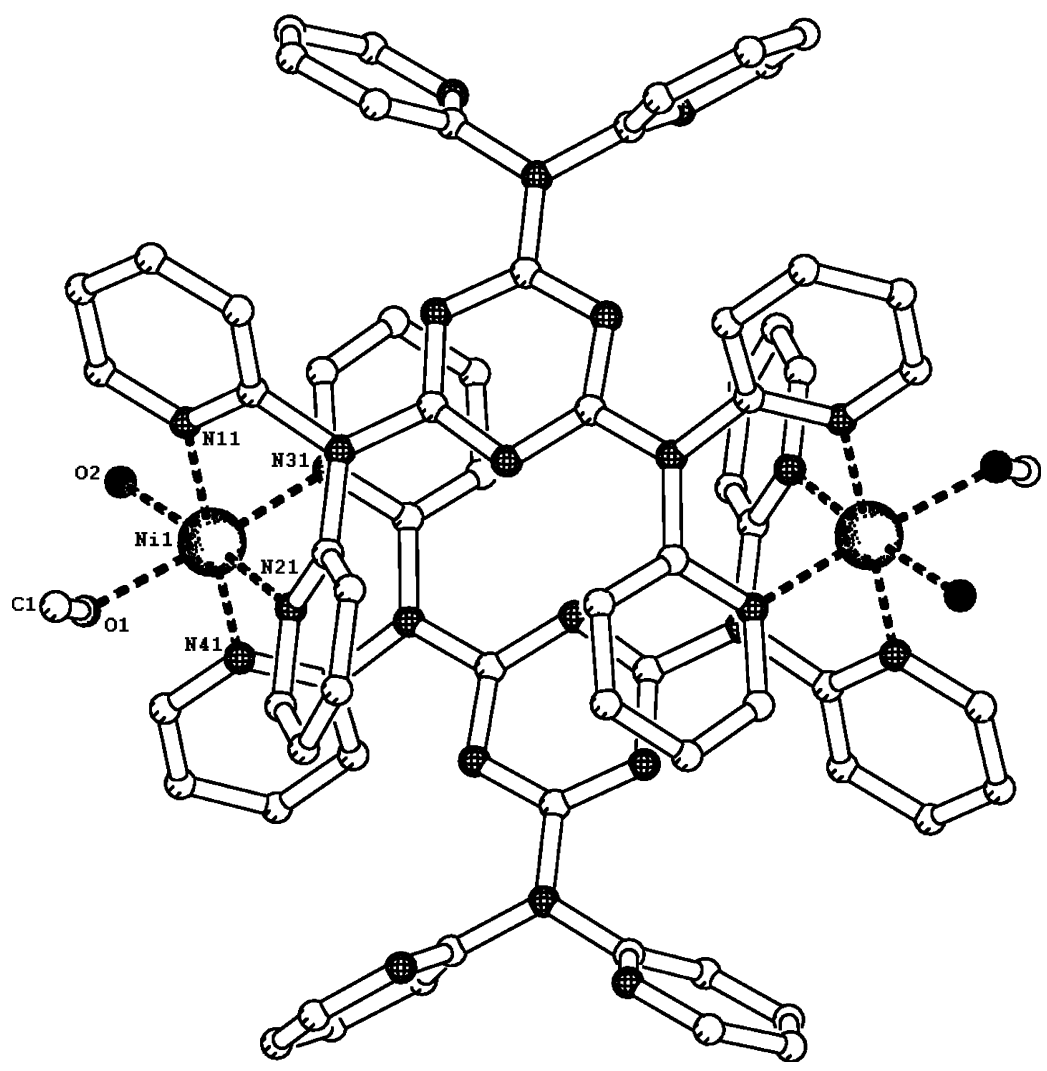

Fig. 6. Platon [21] projection for 3. Hydrogen atoms are omitted for clarity.<smiles>CC(C)(C)c1cc(O)c(O)c(C(C)(C)C)c1</smiles>

Fig. 7. Oxidation of 3,5-di-tert-butylcatechol.

\section{Conclusion}

A simple and versatile method to synthesize rationally designed nitrogen-containing ligands has been developed and discussed in detail. These ligands can be easily prepared in good yield starting from low-cost commercially available materials like 2,4,6-trichloro-1,3,5-triazine (1). Thus, a novel supramolecular hexadecadentate ligand has been synthesized as well as a new nickel complex obtained from one of the polypyridyl ligand reported. The coordination of the multi-directional ligands reported with other metal ions like platinum, palladium or cadmium is currently explored in order to have a better control on the formation of unique molecular networks. The use of these supramolecular ligands in the copper-catalyzed oxidation of DTBC had already shown that the stability and the activity of the catalyst could be improved by incorporating 2,2'- dipyridylamine into a dendritic material. The utilization of these ligands in the manganese-catalyzed epoxidation of alkenes and in the zinc-catalyzed opening of epoxides is under investigation.

\section{Supplementary material}

Crystallographic data for the compounds have been deposited with the Cambridge Crystallographic Data Centre, CCDC Nos. 199610 (2e) and 199611 (3). Copies of this information may be obtained free of charge from The Director, CCDC, 12 Union Road, Cambridge, CB2 1EZ, UK (fax: +44-1223-336-033; e-mail: deposit@ccdc.cam.ac.uk or http://www.ccdc.cam.ac.uk).

\section{Acknowledgements}

Financial support from COST Action D21/003/2001 and the Dutch National Research School Combination Catalysis (HRSMC and NIOK) is gratefully acknowledged. This work was supported in part (M.L., A.L.S.) by The Netherlands Foundation for Chemical Sciences (CW) with financial aid from the Netherlands Organiza- 
tion for Scientific Research (NWO). We are indebted to J. van Brussel for performing the elemental and GC analyses.

\section{References}

[1] J.-M. Lehn, B.O. Kneisel, G. Baum, D. Fenske, Angew. Chem., Int. Ed. Engl. 35 (1996) 1838.

[2] S.R. Batten, B.F. Hoskins, R. Robson, Angew. Chem., Int. Ed. Engl. 36 (1997) 636.

[3] M. Fujita, N. Fujita, K. Ogura, K. Yamaguchi, Nature 400 (1999) 52.

[4] B. Moulton, M.J. Zaworotko, Chem. Rev. 101 (2001) 1629.

[5] J.W. Steed, J.L. Atwood, Supramolecular Chemistry, Wiley, Chichester, 2000.

[6] E.K. van den Beuken, B.L. Feringa, Tetrahedron 54 (1998) 12985.

[7] H. Li, M. Eddaoudi, M. O'Keeffe, O.M. Yaghi, Nature 402 (1999) 276

[8] P. Gamez, P.G. Aubel, W.L. Driessen, J. Reedijk, Chem. Soc. Rev. 30 (2001) 376.

[9] M. Garmouna, H. Blanchoud, M.-J. Teil, M. Blanchard, M. Chevreuil, Water, Air, Soil Pollut. 132 (2001) 1.

[10] B. Klenke, M. Stewart, M.P. Barrett, R. Brun, I.H. Gilbert, J. Med. Chem. 44 (2001) 3440.

[11] H.S. Patel, V.C. Patel, Eur. Polym. J. (2001) 2263.

[12] P. Timmerman, L.J. Prins, Eur. J. Org. Chem. (2001) 3191

[13] A.G. Bielejewska, C.E. Marjo, L.J. Prins, P. Timmerman, F. de Jong, D.N. Reinhoudt, J. Am. Chem. Soc. 123 (2001) 7518.
[14] S.R. Batten, B.F. Hoskins, B. Moubaraki, K.S. Murray, R. Robson, Chem. Commun. (2000) 1095.

[15] C. Seward, J. Pang, S. Wang, Eur. J. Inorg. Chem. (2002) 1390.

[16] P.J. Baesjou, W.L. Driessen, G. Challa, J. Reedijk, J. Am. Chem. Soc. 119 (1997) 12590

[17] P.J. Baesjou, W.L. Driessen, G. Challa, J. Reedijk, J. Mol. Catal. A 110 (1996) 195.

[18] P. de Hoog, P. Gamez, W.L. Driessen, J. Reedijk, Tetrahedron Lett. 43 (2002) 6783

[19] G.M. Sheldrick, SHELXs-97: program for crystal structure solution, University of Göttingen, Göttingen, Germany, 1997.

[20] G.M. Sheldrick, SHELXL-97: program for crystal structure refinement, University of Göttingen, Göttingen, Germany, 1997.

[21] A.L. Spek, PLATON: a multipurpose crystallographic tool, Utrecht University, Utrecht, The Netherlands, 2002.

[22] P. Gamez, P. de Hoog, M. Lutz, W.L. Driessen, A.L. Spek, J. Reedijk, Polyhedron 22 (2003) 205.

[23] P. Gamez, P. de Hoog, O. Roubeau, M. Lutz, W.L. Driessen, A.L. Spek, J. Reedijk, Chem. Commun. (2002) 1488

[24] P. de Hoog, P. Gamez, O. Roubeau, M. Lutz, W.L. Driessen, A.L. Spek, J. Reedijk, New J. Chem. 27 (2003) 18.

[25] R.E.P. Winpenny, J. Chem. Soc., Dalton Trans. (2002) 1.

[26] M. Fujita, Chem. Soc. Rev. 27 (1998) 417

[27] J.B. Trémolières, J.B. Bieth, Phytochem. 23 (1984) 501.

[28] A. Rompel, H. Fischer, D. Meiwes, K. Buldt Karentzopoulos, R. Dillinger, F. Tuczek, H. Witzel, B. Krebs, J. Biol. Inorg. Chem. 4 (1999) 56.

[29] C. Gerdemann, C. Eicken, B. Krebs, Acc. Chem. Res. 35 (2002) 183. 